\title{
Elastofibroma dorsi
}

INSERM

\section{Source}

INSERM. (1999). Orphanet: an online rare disease and orphan drug data base.

Elastofibroma dorsi. ORPHA:228243

Elastofibroma dorsi is a rare, acquired, dermis elastic tissue disorder characterized by a benign, slowly progressive, often bilateral, non-encapsulated lesion, usually presenting as an ill-defined mass under the inferior angle of the scapula (but other locations have been reported), which adheres to the deep layers and presents no local signs of inflammation. It is commonly asymptomatic and discovered inadvertently, but symptoms may include pain and discomfort or stiffness when using the shoulder. The presence of a firm mass masked by the scapula during retropulsion of the shoulder and becoming prominent when the shoulder is displaced toward the front is a frequent sign. Neuromuscular involvement of the upper limb may occur in rare cases. 